$U D C: \mathbf{6 5 7 . 6 3 5}$

JEL Classification: $M 42$

doi: 10.31767/nasoa.1-2.2019.05

\author{
N. I. DOROSH, \\ Dsc (Economics), Professor, \\ Professor of the Department of Accounting and Audit, \\ Kyiv National Taras Shevchenko University; \\ I. V. HOROBETS, \\ Master Student, \\ Department of Accounting and Audit. \\ Kyiv National Taras Shevchenko University; \\ ORCID: https://orcid.org/0000-0002-6357-1834
}

\title{
Organization and Standardization of Sustainability Reporting
}

The objective of the study is to highlight the content, purposes, standards and applications of sustainability reporting, to present a comparative analysis of the sustainability reporting framework from the point of view of internal and external users, to analyze government regulations and best practices of development and presentation of sustainability reporting. Main components of sustainability, definitions of sustainability, content of sustainability reporting, the International Reporting Framework, the reporting content under Global Reporting Initiative (GRI), numbers of companies preparing report by GRI are illustrated. One of the most important tasks of this article is to clarify the position of the Ukrainian business entities with respect to sustainability reporting and outline the ways to improve it by use of world's best practices. A review of sustainability reporting practices at Ukrainian companies is made. It shows that Ukrainian enterprises developing and presenting sustainability reporting based on GRI framework can be divided into groups: large multinational companies with divisions in Ukraine (Coca-Cola, Deloitte, EY, KPMG, British American Tobacco, Nestle, etc.); Ukrainian nature companies (Arcelor, VEON, Energoatom (first state company in Ukraine adopted GRI) companies of SKM group: DTEK, Ukrtelecom, UMG, etc.). The numbers of Ukrainian companies who develop, present and disclose information on sustainability remain to be low due to economic, geo-politic, socio-cultural factors. Recommendations on further development of sustainability reporting in Ukraine are given.

Keywords: sustainability, sustainability reporting, non-financial information, integrated reporting, IR framework, Global Reporting Initiative.

Н. І. ДОРОШ,

доктор економічних наук, професор професор кафедри бухгалтерського обліку та аудиту,

Київський національний університет імені Тараса Шевченка;

I. В. ГОРОБЕЦЬ, магістрант,

кафедра бухгалтерського обліку та аудиту,

Київський національний університет

імені Тараса Шевченка

\section{Організація та стандартизація звітності 3 питань сталості}

Розкриті питання, пов'язані з сутністю, призначенням, змістом, стандартами складання звітності з питань стійкості в глобальному контексті. Проаналізовано ситуацію з розробленням і поданням такої звітності на українських підприємствах. Зроблено висновок, щзо практика складання і подання відповідних звітів в Украӥні не набула поширення внаслідок економічних, політичних, соціальних і культурних чинників. Надано рекомендації з подальшому розвитку звітності з питань стійкості в Украӥні.

(C) N. I. Dorosh, I. V. Horobets, 2019 
Ключові слова: стійкість, звітність з питань стійкості, нефінансова інформація, інтегрована звітність, рамки інтегрованої звітності, глобальна інічиіатива у сфері звітності.

Н. И. ДОРОШ,

доктор экономических наук, профессор, профессор кафедры бухгалтерского учета и аудита, Киевский национальный университет имени Тараса Шевченко;

И. В. ГОРОБЕЦ, магистрант, кафедра бухгалтерского учета и аудита, Киевский национальный университет имени Тараса Шевченко

\section{Организация и стандартизация отчетности по вопросам устойчивости}

Раскрыты вопросы, связанные с сущзностью, назначением, содержанием, стандартами составления отчетности по вопросам устойчивости в глобальном контексте. Проанализирована ситуация с разработкой и представлением такой отчетности на украинских предприятиях. Сделан вывод, что практика составления и подачи соответствующих отчетов в Украине не получила широкого распространения вследствие экономических, политических, сочиальных и культурных факторов. Даныл рекомендации по дальнейшему развитию отчетности по вопросам устойчивости 8 Украине.

Ключевые слова: устойчивость, отчетность по вопросам устойчивости, нефинансовая информация, интегрированная отчетность, рамки интегрированной отчетности, глобальная иницииатива в сфере отчетности.

Introduction. Since the beginning of the 1990s, pressure has increased on companies to be more transparent about the social and environmental impacts of their business activities. This pressure has come from a variety of stakeholders: consumers concerned about the ethical implications of their purchases, shareholders seeking to integrate social and environmental risks into their investment decisions, communities and civil society organizations demanding to know the value that companies contribute to society, employees who want assurance that the company they work for is a good corporate citizen.

Sustainability reporting in the corporate setting is an important factor to improve a company's green initiatives and its relationship with investors and clients, in line with stakeholders' demand for transparency and accountability. Sustainability reporting in addition helps companies maintain and increase their value.

Literature review. Sustainability reporting becomes more popular object of different economists, sociologists, publicists since increasing attention to the problem from the side of society, governance and own corporate social responsibility. Main objects of their studies are interpretation of sustainability standards, impact of the sustainability way of doing business to our ecosystem and market.

Systematic nature of the implementation of initiatives on corporate social responsibility, achieving goals of sustainable development by companies give the sustainability reporting significance and acknowledgment from stakeholders.

A comparative analysis on the best practice of non-financial reporting presentation and its development prospects are described in the work of D. G. Szabó and K. E. Sørensen [20; 21]. Sectoral context is the subject of research by A. Doni, F. Gasperini [15].

The features of formation and submission of sustainability reporting is are highlighted in the works of severalforeign authors: A. Filipova-Slancheva [14], A. Skouloudis, K. Evangelinos, F. Kourmousis, T. Vuontisjärvi, S. Idowu, B. Towler, D. Dhaliwal, O. Li, A. Tsang, Y. Yang [12]. 
Some aspects of convergent processes in financial reporting submission and its audit are disclosed in the works of N. I. Dorosh [13], S. F. Golov, S. Y. Zubilevich [22], V. M. Parkhomenko [18], O. A. Petryk [19]. In general, the study of sustainability reporting of Ukrainian companies requires a systematic approach because of the necessity of implementing the specific rules and directives.

The article's objective is in summing up the information related with the content, purposes, standards and applications of sustainability reporting, and to highlight the sustainability reporting practices in Ukraine.

Results. Sustainability is complex concept, most often defined as meeting the needs of the present without compromising the ability of future generations to meet theirs. It has three main pillars: economic, environmental, and social. These three pillars are informally referred to as people, planet and profits (see Figure 1).

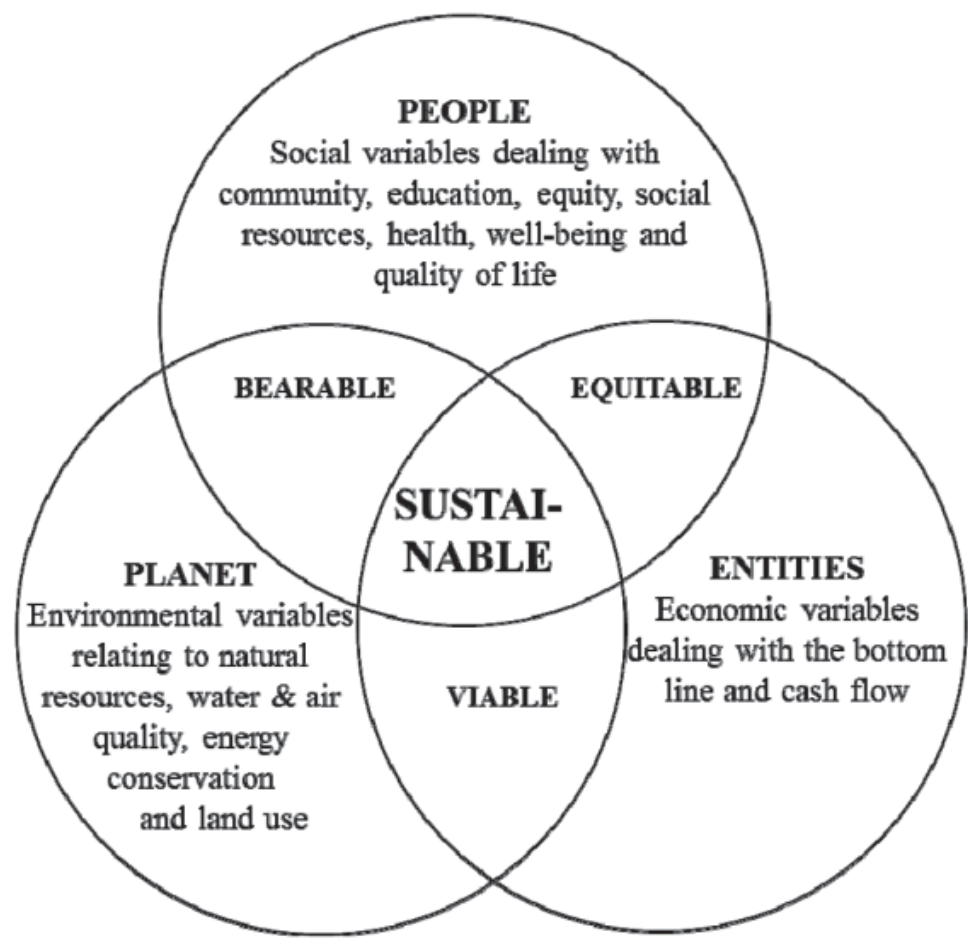

Figure 1. Main components of sustainability

Source: developed by the authors

Environmental Sustainability: ecological integrity is maintained, all of earth's environmental systems are kept in balance while natural resources within them are consumed by humans at a rate where they are able to replenish themselves.

Economic Sustainability: human communities across the globe are able to maintain their independence and have access to the resources that they require, financial and other, to meet their needs. Economic systems are intact and activities are available to everyone, such as secure sources of livelihood.

Social Sustainability: universal human rights and basic necessities are attainable by all people, who have access to enough resources in order to keep their families and communities healthy and secure. Healthy communities have just leaders who ensure personal, labor and cultural rights are respected and all people are protected from discrimination.

If go deeper into details may be found different meaning of category sustainability based on main stakeholders who use it. The most common of them are determined by international unions, specific organization linked with sustainability, scientists and publicists (see Table 1). 
Definitions of sustainability

\begin{tabular}{|l|l|}
\hline Source & Definition \\
\hline $\begin{array}{l}\text { Global Reporting Ini- } \\
\text { tiative (GRI) }\end{array}$ & $\begin{array}{l}\text { How an organization contributes, or aims to contribute in the future, } \\
\text { to the improvement or deterioration of economic, environmental } \\
\text { and social conditions, developments, and trends at the local, re- } \\
\text { gional or global level }\end{array}$ \\
\hline $\begin{array}{l}\text { International Integrated } \\
\text { Reporting Council } \\
\text { (IIRC) }\end{array}$ & $\begin{array}{l}\text { 4 capitals - intellectual, social and relationship, human, and natural } \\
\text { - that (combined with financial and manufactured capital) that an } \\
\text { organization uses and depends on }\end{array}$ \\
\hline $\begin{array}{l}\text { Sustainability Account- } \\
\text { ing Standards Board } \\
\text { (SASB) }\end{array}$ & $\begin{array}{l}\text { Sustainability is ESG dimensions of a company's operation and } \\
\text { performance }\end{array}$ \\
\hline $\begin{array}{l}\text { US Environmental } \\
\text { Protection Agency }\end{array}$ & $\begin{array}{l}\text { Sustainability is based on a simple principle: Everything that we } \\
\text { need for our survival and well-being depends, either directly or } \\
\text { indirectly, on our natural environment. To pursue sustainability } \\
\text { is to create and maintain the conditions under which humans and } \\
\text { nature can exist in productive harmony to support present and } \\
\text { future generations }\end{array}$ \\
\hline $\begin{array}{l}\text { American Institute of } \\
\text { CPAs (AICPA) }\end{array}$ & $\begin{array}{l}\text { "Triple bottom-line" considerations of 1) economic viability, 2) so- } \\
\text { cial responsibility, and 3) environmental responsibility }\end{array}$ \\
\hline Merriam Webster & Able to be used without being completely used up or destroyed \\
\hline $\begin{array}{l}\text { Harvard Business } \\
\text { Review }\end{array}$ & $\begin{array}{l}\text { An activity is sustainable when all costs are internalized, because } \\
\text { if the costs are too high, the activities stop }\end{array}$ \\
\hline United Nations & $\begin{array}{l}\text { Development that meets the needs of the present without compro- } \\
\text { mising the ability of future generations to meet their own needs }\end{array}$ \\
\hline $\begin{array}{l}\text { World Commission on } \\
\text { Environment and De- } \\
\text { velopment (WCED) }\end{array}$ & $\begin{array}{l}\text { Development that meets the needs of the present without compro- } \\
\text { mising the ability of future generations to meet their own needs }\end{array}$ \\
\hline
\end{tabular}

Source: developed by the authors on the basis of $[5 ; 7]$

From the above determination sustainability is development and institutional operating practices which cause and link economic, environmental, and social dimensions with the purpose to meet the needs of present users without compromising the ability of future generations to meet their own needs, particularly with regard to use and waste of natural resources.

A sustainability report is a report published by a company or organization about the economic, environmental and social impacts caused by its everyday activities. A sustainability report also presents the organization's values and governance model, and demonstrates the link between its strategy and its commitment to a sustainable global economy.

Sustainability reporting enables organizations to consider their impacts of wide range of sustainability issues, enabling them to be more transparent about the risks and opportunities they face.

Sustainability reporting may be called non-financial reporting, triple bottom line reporting, corporate social responsibility (CSR) reporting [2].

Sustainability reporting is one of the integral components of integrated reporting. Integrated reporting aims to incorporate everything from strategy through risk management; from financial reporting to the inclusion of other capitals (societal and environmental impacts), and to meet the needs of a broad a group of stakeholders. It intends to interlink these elements in a way that makes their interdependencies clear. In doing so, it may represent the most significant change to the reporting rulebook in years.

A variety of concerns, including pollution, climate change, human rights issues and economic crises, have prompted the development of ongoing public discourse about the role 
of business in society and the need for greater transparency, sustainability and responsibility in business. Elements described below is shown in different parts of reporting content is the subject matter about which requirement developers demand or request sustainability information through reporting requirements. Reporting content of sustainability reporting falls into the following categories in Figure 2.
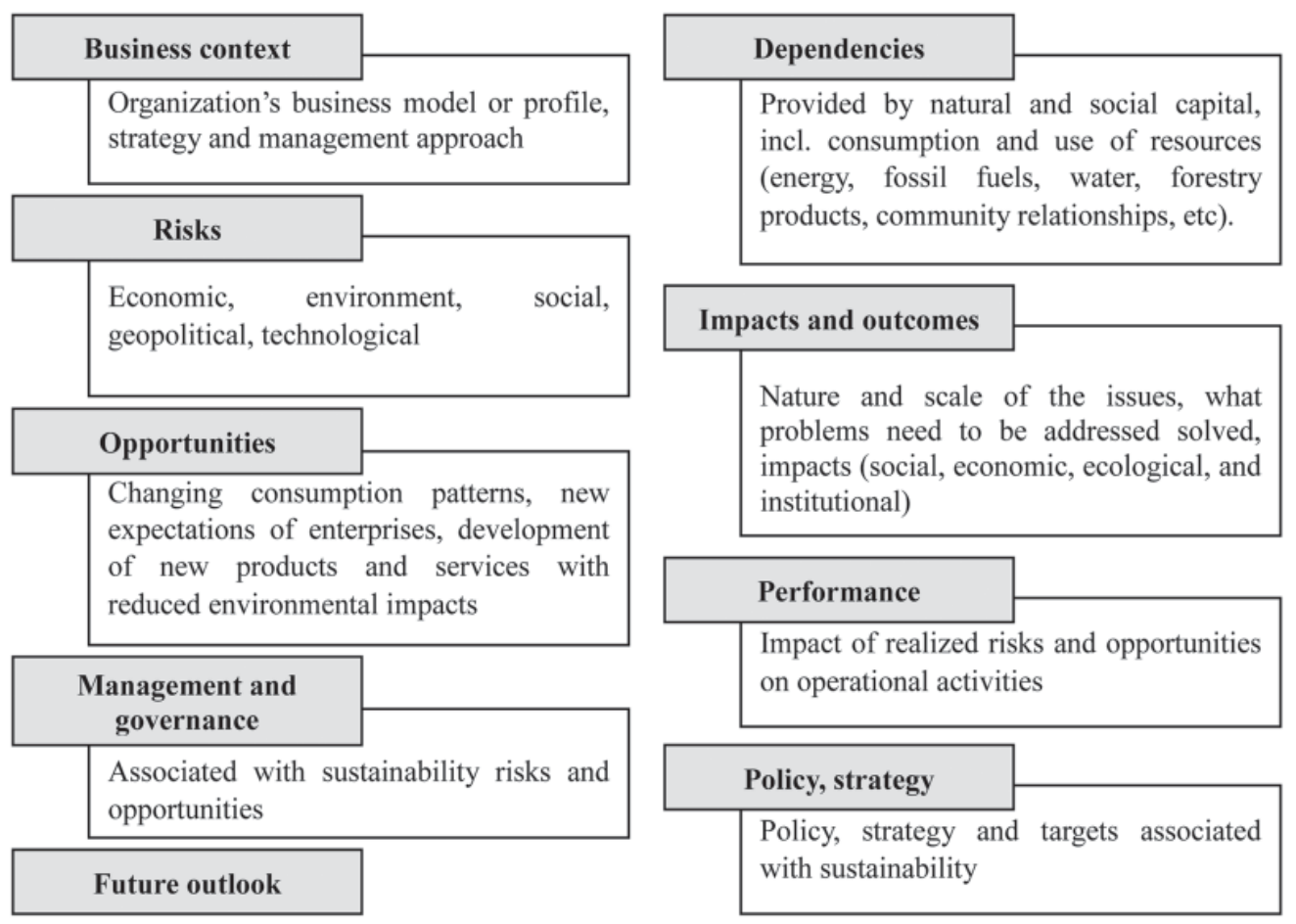

Figure 2. Reporting content of sustainability reporting

Source: developed by the authors

One of the most common reasons to implement sustainability reporting by companies is creation addition value. Key elements of value creation by sustainability:

- $\quad$ Reducing costs: water usage, energy usage.

- Optimizing efficiency. Through "zero waste" initiative, big corporations receive earnings against business and environmental risks, eliminating divisions with significant waste products (e. g., carpets and nylons) [8].

- New products / technologies. Companies focus on sustainability innovation led to new products and breakthroughs such as solar roof shingles and hybrid batteries, which helped shift core business to advanced materials and high-tech energy.

- New business models and differentiated value proposition.

- Competitive advantage. Companies that understand the implications of sustainability to their business models can use this information to both enhance and develop new products and services: first mover advantage and reputational position in new and/ or growing markets.

- Access to capital and markets. There is growing evidence of investors assessing organizations' sustainability performance in the context of good corporate governance and risk management. The transparency of how (well) an organization is addressing sustainability builds trust with investors. Sustainability performance has been shown to improve brand and reputation, and therefore the ability to attract investment and enter new markets.

- Managing risks. Organizations face a variety of sustainability risks along their operation activity - for example some have regulatory implications leading to monetary fines, others have reputational impacts leading to loss of customers or 
even loss of investors. Integration of sustainability risks into the overall governance architecture of an organization suggests that such organizations outperform those that do not.

Reporting requirements are the provisions, including legislation, standards, protocols, frameworks, codes, principles and guidance that set out what subject matter an organization should report and how it should determine, prepare and present information in sustainability reports and through other reporting channels.

Regulation and legislation are "mandatory" or "statutory" provisions for reporting on sustainability generally or on particular aspects of sustainability. Provisions may apply at state, federal, regional or national level and may be found in securities, financial, governance, environmental and other bodies of law.

Sustainability standards systems are market-based tools, designed to address the most pressing social and environmental challenges of our time. These standards have a proven track record of delivering impacts at a global scale on the sustainability issues that matter most (GRI Standards, Sustainability Accounting Standards Board guidelines, ISO Standards, ASTM Standards, etc.)

Protocols, frameworks, codes, principles and guidance which are developed through due process and stakeholder engagement, referenced in legislation as representing the approach that should be taken to comply with legal requirements, have become so widely adopted as to constitute de-facto standards.

Rating and indices which is applicable to certain corporate information on sustainability (Bloomberg ESG Data Service, Corporate Knights Global 100, Dow Jones Sustainability Index (DJSI), Institutional Shareholder Services (ISS), MSCI ESG Research, RepRisk, Sustainalytics Company ESG Reports, Thomson Reuters ESG Research Data).

General concept and purpose of sustainability reporting is the same in all countries: is to communicate the reporting organization's performance (the end result of management's processes and actions in relation to corporate goals) over the reporting period, whether for compliance or stakeholder information purposes.

However requirements, methodology of preparation and presentation of integrated and sustainability reports are developed by different organizations and regulated by different standards (like IFRS is mostly common in EU, GAAP in USA for financial reporting).

Major providers of sustainability reporting guidance include:

- Global Reporting Initiative (GRI)

- $\quad$ The International Integrated Reporting Council (IIRC)

- The Organization for Economic Co-operation and Development (OECD)

- The United Nations Global Compact (the Communication on Progress)

- The International Organization for Standardization (ISO 26000, International Standard for social responsibility)

- Sustainability Accounting Standards Board (SASB)

Table 2

Summary of the offerings, purpose and reporting channels relating to four specialist sustainability reporting requirement developers

\begin{tabular}{|l|l|l|l|}
\hline Organization & \multicolumn{1}{|c|}{ Offering } & \multicolumn{1}{|c|}{ Purpose } & $\begin{array}{l}\text { Where information is } \\
\text { to be reported? }\end{array}$ \\
\hline 1 & \multicolumn{1}{|c|}{2} & \multicolumn{1}{c|}{4} \\
\hline $\begin{array}{l}\text { The } \\
\text { International } \\
\text { Reporting } \\
\text { Council } \\
\text { (IIRC) }\end{array}$ & $\begin{array}{l}\text { The International } \\
\text { Integrated Reporting } \\
\text { <IR }>\text { Framework. }\end{array}$ & $\begin{array}{l}\text { The primary purpose of } \\
\text { the <IR> Framework is } \\
\text { to enable organizations } \\
\text { to produce 'integrated } \\
\text { reports' and explain to } \\
\text { providers of financial } \\
\text { capital how an } \\
\text { organization creates value } \\
\text { over time; it may also } \\
\text { benefit other stakeholders. }\end{array}$ & $\begin{array}{l}\text { An integrated report } \\
\text { may be prepared } \\
\text { in response to } \\
\text { existing compliance } \\
\text { requirements, and may } \\
\text { be either a standalone } \\
\text { report or included } \\
\text { as a distinguishable, } \\
\text { prominent and } \\
\text { accessible part of } \\
\text { another report or } \\
\text { communication. }\end{array}$ \\
\hline
\end{tabular}


Table 2

\begin{tabular}{|c|c|c|c|}
\hline 1 & 2 & 3 & 4 \\
\hline $\begin{array}{l}\text { Sustainability } \\
\text { Accounting } \\
\text { Standards } \\
\text { Board } \\
\text { (SASB) }\end{array}$ & $\begin{array}{l}\text { Sector-specific } \\
\text { Sustainability } \\
\text { Accounting Standards. }\end{array}$ & $\begin{array}{l}\text { To assist companies in } \\
\text { disclosing financially } \\
\text { material, decision- } \\
\text { useful sustainability } \\
\text { informa-tion to investors. }\end{array}$ & $\begin{array}{l}\text { The US Securities and } \\
\text { Exchange Commission } \\
\text { (SEC) has mandatory } \\
\text { filing requirements, } \\
\text { such as forms 10-K } \\
\text { and 20-F. The SASB } \\
\text { Standards are designed } \\
\text { to support compliance } \\
\text { with these requirements. }\end{array}$ \\
\hline $\begin{array}{l}\text { Global } \\
\text { Reporting } \\
\text { Initiative } \\
\text { (GRI) }\end{array}$ & $\begin{array}{l}\text { Sustainability } \\
\text { Reporting Framework } \\
\text { (including Guidelines } \\
\text { and sector guidance). }\end{array}$ & $\begin{array}{l}\text { The report should cover } \\
\text { aspects that reflect the } \\
\text { organization's significant } \\
\text { economic, environmental, } \\
\text { and social impacts; or } 2 \text {. } \\
\text { substantively influence } \\
\text { the assessments and } \\
\text { decisions of stakeholders }\end{array}$ & $\begin{array}{l}\text { Any type of document } \\
\text { that requires such } \\
\text { disclosure. }\end{array}$ \\
\hline CDP & $\begin{array}{l}\text { Reporting programs on } \\
\text { climate change, forests } \\
\text { and water, including } \\
\text { general and sector- } \\
\text { specific guidance. }\end{array}$ & $\begin{array}{l}\text { The guidance helps } \\
\text { organizations to } \\
\text { measure and manage } \\
\text { environmental risk and } \\
\text { provides decision makers } \\
\text { with information about } \\
\text { obtaining evidence and } \\
\text { insight to drive change. }\end{array}$ & $\begin{array}{l}\text { CDP's online reporting } \\
\text { system. }\end{array}$ \\
\hline $\begin{array}{l}\text { The } \\
\text { Organization } \\
\text { for } \\
\text { Economic } \\
\text { Co-operation } \\
\text { and } \\
\text { Development }\end{array}$ & $\begin{array}{l}\text { OECD Guidelines } \\
\text { for Multinational } \\
\text { Enterprises }\end{array}$ & $\begin{array}{l}\text { The guidelines include } \\
\text { principles and standards } \\
\text { for responsible business } \\
\text { conduct for multinational } \\
\text { corporations operating } \\
\text { in or from countries } \\
\text { adhering to the } \\
\text { Declaration }\end{array}$ & $\begin{array}{l}\text { National Contact Point } \\
\text { (NCP) }\end{array}$ \\
\hline
\end{tabular}

Source: developed by the authors

Integrated Reporting Framework applies principles and concepts that are focused on bringing greater cohesion and efficiency to the reporting process, and adopting "integrated thinking" as a way of breaking down internal silos and reducing duplication. It improves the quality of information available to providers of financial capital to enable a more efficient and productive allocation of capital. Its focus on value creation, and the "capitals' used by the business to create value over time, contributes towards a more financially stable global economy.

The Framework was released following extensive consultation and testing by businesses and investors in all regions of the world, including the 140 businesses and investors from 26 countries that participated in the IIRC Pilot Program. The purpose of the Framework is to establish Guiding Principles and Content Elements that govern the overall content of an integrated report, and to explain the fundamental concepts that underpin them.

As firms worldwide have embraced sustainability reporting, another most widely adopted framework has been the GRI Sustainability Reporting Framework (GRI Framework or framework).

The GRI framework is a collection of reporting guidance documents - all of which were developed through global, multi-stakeholder consultative processes - designed to assist companies in preparing sustainability reports and ESG disclosures. These guidance documents are periodically revised to ensure that they continue to meet the needs of $21 \mathrm{st}$ century business and society. 


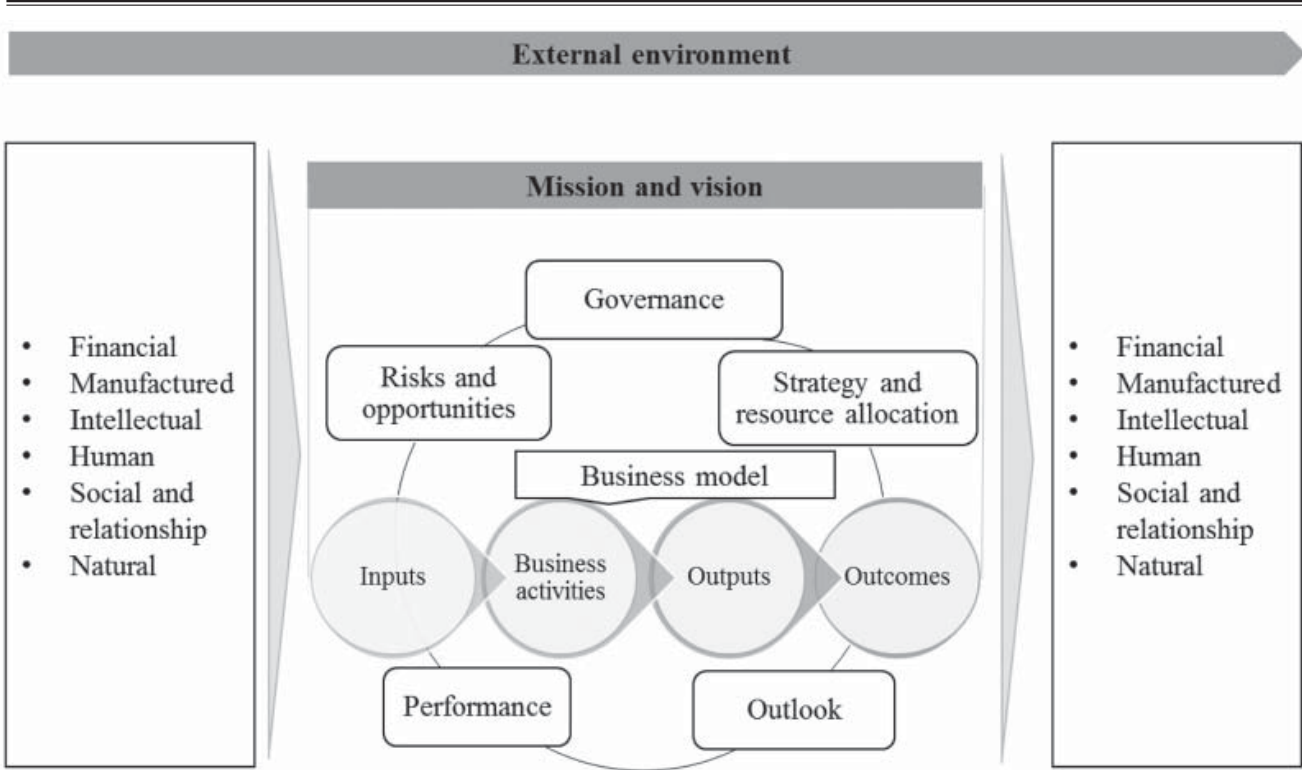

Value creation (preservation, diminution) over time

Figure 3: The International $<$ IR $>$ Framework

Source: developed by the authors on the basis of $[3 ; 10]$

The GRI Standards represent global best practice for reporting publicly on a range of economic, environmental and social impacts. Sustainability reporting based on the Standards provides information about an organization's positive or negative contributions to sustainable development.

The modular, interrelated GRI Standards are designed primarily to be used as a set, to prepare a sustainability report focused on material topics. The three universal Standards are used by every organization that prepares a sustainability report. An organization also chooses from the topic-specific Standards to report on its material topics - economic, environmental or social.

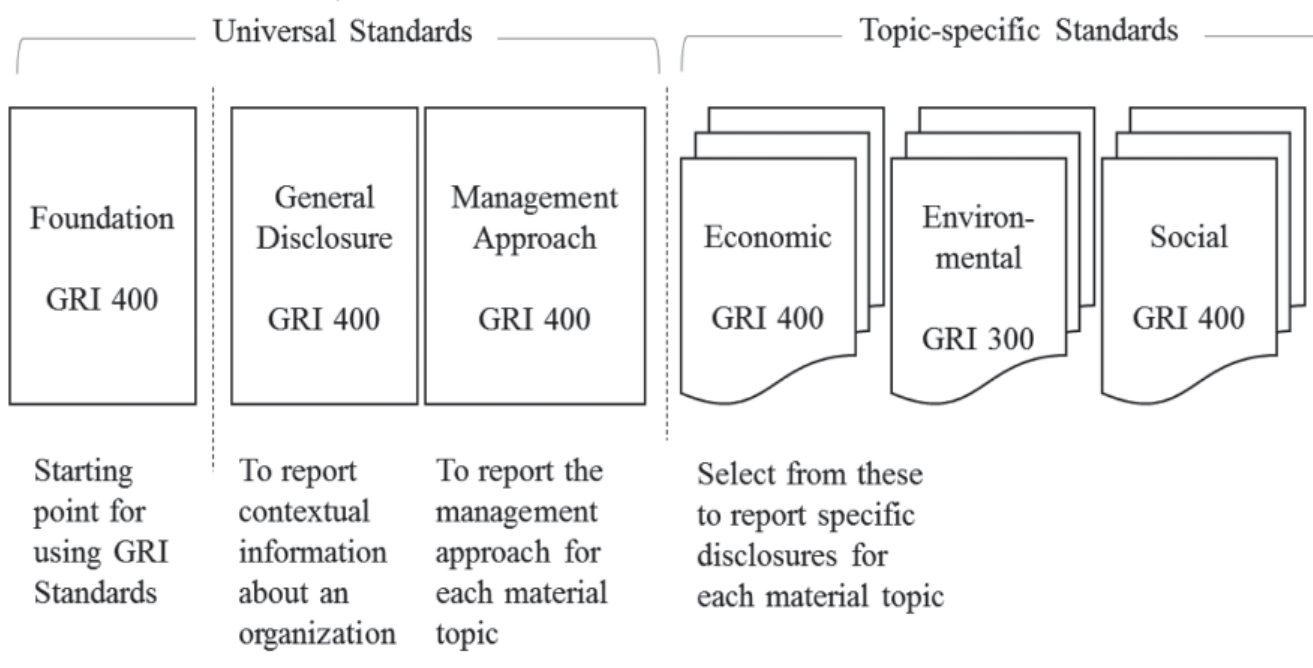

Figure 4. GRI reporting content

Source: developed by the authors 
Preparing a report in accordance with the GRI Standards provides an inclusive picture of an organization's material topics, their related impacts, and how they are managed. An organization can also use all or part of selected GRI Standards to report specific information.

The key benefit of using the GRI framework, in addition to standardization of reports, is guidance on material issues. The GRI emphasizes that a company consider those environmental and social aspects that are most significant to its key stakeholders and have the most significant impacts on its business - or result from it.

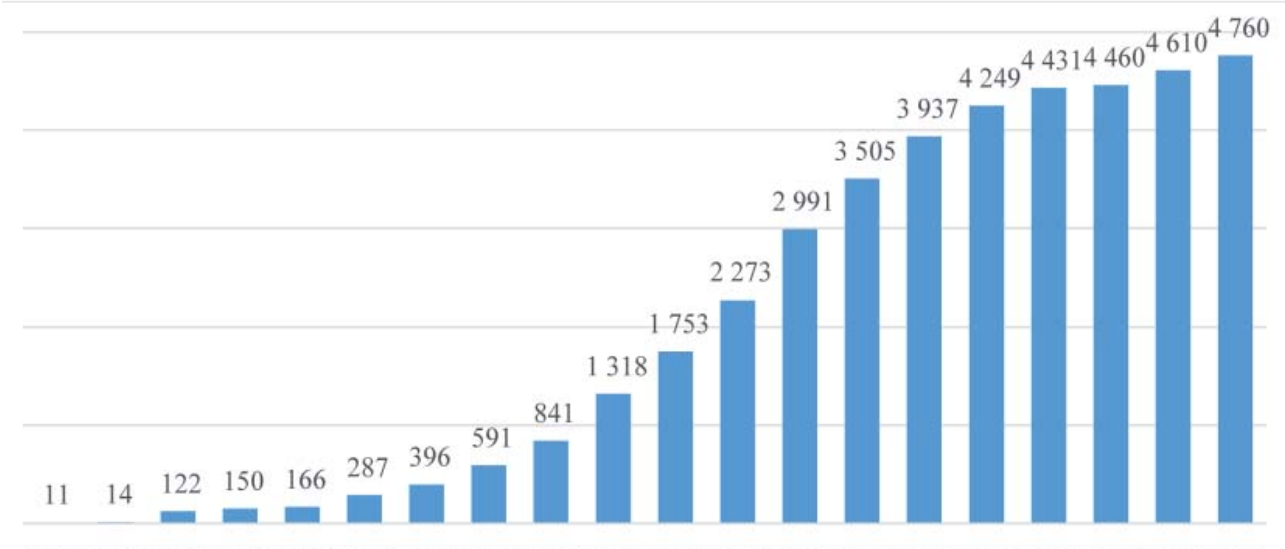

19992000200120022003200420052006200720082009201020112012201320142015201620172018

Figure 5. Number of companies preparing report by GRI

Source: developed by the authors on the basis of Baker Tilly report level.

In Ukraine sustainability concept has not developed a lot, especially at the corporate

Based adoption the 17 Sustainable Development Goals (SDGs) during the Sustainable Development Summit in New York on 25 September 2015 by United Nations (UN) the Government of Ukraine must incorporate the SDGs into Government Strategic Policy Papers (GSPPs) to the greatest extent possible and ensure their implementation. All sectors, i. e. public, private and civil, must be involved in the process, since the SDGs are comprehensive, covering environmental, economic and social areas, and in accordance with the principle of "leaving no one behind". The next important phases of the process are to identify gaps in Ukrainian policy documents with regard to SDGs, highlight risks and detect systemic obstacles to meeting Ukraine's goals.

According to the requirement were developed draft of Sustainable Development Strategy for Ukraine by 2030 and the National Action Plan on the Strategy Implementation by 2020 are the results of the analytical work carried out by Ukrainian experts with support from the United Nations Development Program in Ukraine and the Global Environment Facility within the implementation of "Integrating RIO Conventions Provisions into Ukraine's National Policy Framework" project.

The proposed draft Strategy is regarded as a framework document that will determine the strategic direction of Ukraine's long-term development. The principal aspect of the document development was the consideration of the Sustainable Development Goals, adapted for Ukraine by 2030, along with the key provisions of the updated EU Sustainable Development Strategy. The Strategy of Sustainable Development of Ukraine by 2030 and the National Action Plan by 2020, on condition that they are approved at state level, could become an effective tool for future implementation of the principles of balanced regional development.

Ukraine enterprises develop and present sustainability reporting based on GRI framework. They can be provisionally divided into groups:

- Large multinational companies with divisions in Ukraine (Coca-Cola, Deloitte, EY, KPMG, British American Tobacco, Nestle, etc.) 
- Ukrainian nature companies (Arcelor, VEON, Energoatom (first state company in Ukraine adopted GRI) companies of SKM group: DTEK, Ukrtelecom, UMG, etc.)

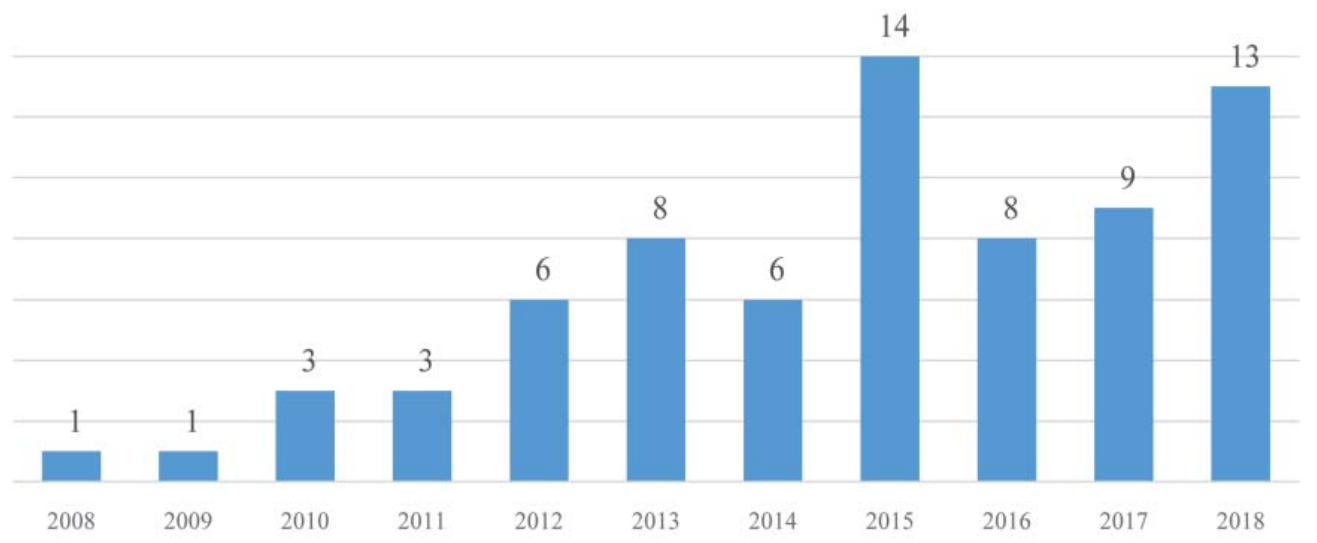

Figure 6. Number of Ukrainian companies preparing report by GRI

Source: developed by the authors on the basis of Baker Tilly report

Number of companies who develop, present and disclose information on sustainability is low due to economical, geopolitical, socio-cultural factors and impact of past of the country:

- lack of understanding the importance of sustainable development on top level of Ukrainian companies;

- hard to define monetary value for company of keeping sustainability principles;

- impact of socio-cultural environment and mentality of Ukrainians, who have no clear understanding of business responsibility to society and the need to implement sustainable development initiatives.

- low level of government control and adopted model of sustainability reporting at the national level;

- lack of accounting and methodological provision of reporting indicators, accessible and understandable sustainability reporting guidance;

- commercial focus of different stakeholders, lack of interest to sustainability position of market subjects.

Main recommendations for further development of sustainability reporting in Ukraine:

- develop sustainability programs, policies at the national level;

- adopt sustainability reports framework at national level to provide presentation of information with quality and quantitative features;

- educate top management and every employees in value, main principles, guidelines, reporting tools and techniques;

- involve corporations to collaboration on corporate social responsibility.

Sustainability report usually includes several blocks of information about company: financial performance for the last years, mission, values, description of social initiatives, employees, clients' relations, relations with governance and society. The most important part for different stakeholders (current/potential investors, customers, employees, governmental and international organizations, financial institutions, etc.) is about GRI indicators. Report by GRI indicators includes such parts: economic efficiency, corruption, materials, water, pollutions, energy, employment, etc.

Conclusions. Sustainability reporting builds on existing business management tools and concepts and applies them in a broader context in response to a complex and highly interactive social, environmental, and economic environment. It builds on conventional business management techniques and applies them with a focus on triple bottom line and life cycle management. It requires a sophisticated approach of integrating nonfinancial, sustainable performance measures into the traditional reporting of an organization.

The challenge of sustainability for business organizations is to understand and extract value from sustainability reporting which provides benefits and transform business operations. 
Sustainability reporting without strategic purpose provide a little of benefits for the companies, society, usually may result in information that is nice to know, but which costly to obtain.

Sustainability is the basic principle of operations in EU, USA companies. There are different frameworks and concepts to sustainability reporting, which are similar and have the same goals.

However, in Ukraine social responsibility reporting doesn't adopted by most companies. Only 13 companies in 2018 provide reports based on GRI framework. Great experience from other countries allows Ukrainian companies to implement sustainability concept and reports in further faster and in the most effective way.

Developing an understanding of sustainability reporting and implementing it by companies are competitive advantage in a long-term prospective. Companies who build operations in sustainable way increase their value, reduce costs, prevent and mitigate risks, increase reputation and build stable brand. Ukrainian companies have a great opportunity to build sustainability reporting based on world's best practices which are already bringing positive results.

\section{References}

1. Directive on the disclosure of non-financial and diversity information (Directive 2014/95/EU). Retrieved from https://eur-lex.europa.eu/legal-content/EN/ TXT/?uri=CELEX\%3A32014L0095

2. GRI, CSR Europe, 2017, Member State Implementation of Directive 2014/95/EU. Retrieved from https://www.globalreporting.org/resourcelibrary/nfrpublication $\% 20$ online_version.pdf

3. The International $<\mathrm{IR}>$ Framework, The International Integrated Reporting Council ('the IIRC'), Dec 2013. Retrieved from http://integratedreporting.org/resource/internationalir-framework/

4. A Directors' Guide to Integrated Reporting, Deloitte, 2015. Retrieved from https://www2. deloitte.com/content/dam/Deloitte/na/Documents/audit/na_za_Directors_Guide_on_ Integrated Reporting.pdf

5. CDP, CD $\overline{S B}$, GRI, IASB, IIRC, ISO and SASB (2016). Statement of Common Principles of Materiality of the Corporate Reporting Dialogue. Retrieved from http:// corporatereportingdialogue.com/wp-content/uploads/2016/03/Statement-of-CommonPrinciples-of-Materiality.pdf

6. GRI, 2017, Carrots and Sticks: Sustainability Reporting Policies Worldwide. Retrieved from https://www.globalreporting.org/resourcelibrary/Carrots-and-Sticks.pdf

7. Mapping the sustainability reporting landscape: Lost in the right direction, ACCA, 2016. Retrieved from https://www.cdsb.net/harmonization/593/mapping-sustainabilityreporting-landscape-lost-right-direction

8. Sustainability 101: Trends, drivers, and why it's important / Engineering and Construction Conference, Deloitte, 2017. Retrieved from https://www2.deloitte.com/ content/dam/Deloitte/us/Documents/Real\%20Estate/us-engineering-constructionsustainability-101.pdf

9. Sustainability reports: Coca-Cola, Deloitte, EY Arcelor, DTEK, etc.

10. The new International Integrated Reporting Framework: A review guide for Audit Committee members, Deloitte, 2015. Retrieved from https://www2.deloitte.com/nz/en/ pages/risk/articles/new-international-integrated-reporting-framework.html

11. Value of sustainability reporting: A study by EY and Boston College Center for Corporate Citizenship EY, 2016. Retrieved from https:/www.ey.com/us/en/services/ specialty-services/climate-change-and-sustainability-services/value-of-sustainabilityreporting

12. Dhaliwal D., Li O. Z., Tsang A. H., Yang Y. G. (2015). Voluntary non-financial disclosure and the cost of equity capital: The case of corporate social responsibility reporting (Working Paper University of Arizona). Tucson: University of Arizona. Retrieved June 4, 2015. Retrieved from http:// papers.ssrn.com/sol3/papers.cfm?abstract $\mathrm{id}=1343453$

13. Dorosh N. I. (2016). The financial-environmental audit: the nature and methods. Retrieved from // http://www.agrosvit.info/pdf/22_2016/3.pdf 
14. Filipova-Slancheva A. (2015). Non-financial Reporting in Bulgaria - Status and Challenges. Retrieved from https://www.researchgate.net/publication/300249623_Nonfinancial Reporting in Bulgaria - Status and Challenges

15. Gasperini A., Doni F. (2015). Sustainability Reporting and Value Relevance: Empirical Evidence from the Beverage Industry. In IFKAD 2015 International Forum on Knowledge Asset Dynamics. 10-12 June 2015. Bari Italy Culture, Innovation and Entrepreneurship: Connecting the Knowledge Dots. PROCEEDINGS (pp. 551-566). Matera: IFKAD. Retrieved from https://boa.unimib.it/handle/10281/96568?mode=full.168

16. Makarenko I., Sirkovska N. (2017). Transition to sustainability reporting: evidence from EU and Ukraine. Business Ethics and Leadership, vol. 1, issue 1, 16. Retrieved from https://essuir.sumdu.edu.ua/bitstream/123456789/61541/1/Makarenko_Sirkovska.pdf

17. Lament M. (2015). Trends in Corporate Social Responsibility (CSR) reporting. Journal of Economic Practices and Theories, 5(4), 22-25.

18. Parkhomenko V. (2014), Yevrokonverhentsiya bukhhalterskoho obliku [Euroconvergence of accounting]. Bukhhalterskyy oblik i audit - Accounting and audit, 8, 3-4 [in Ukrainian].

19. Petryk O. A. (2011). Problemy adaptatsii zakonodavstva u sferi audytu do polozhen 43 Dyrektyvy YeS ta Zelenoi knyhy "Polityka audytu: uroky kryzy" [The problem of adaptations the legislation to audit provi-sions CHZ EU Directive and the Green Paper "Audit Policy: Lessons from the crisis"]. Visnyk Lvivskoi Komertsiinoi Akademii Bulletin of Lviv Commercial Academy, 265-268 [in Ukrainian].

20. Szabó D. G., Sørensen K. E. (2015). New EU Directive on the Disclosure of NonFinancial Information (CSR), Nordic \& European Company Law Working Paper No. 15-01, 15 May 2015. Retrieved from https://papers.ssrn.com/sol3/papers.cfm?abstract_ $\mathrm{id}=2606557$

21. Szabó D. G., Sørensen K. E. (2016). Pursuing CSR Policy in Groups of Undertakings - Insights from the Practices of Danish Groups, Nordic \& European Company Law Working Paper No. 16-06, 17 Nov 2016. Retrieved from https://papers.ssrn.com/sol3/ papers.cfm?abstract_id $=2871030$

22. Zubilevych S. (2014)). Oblikova Dyrektyva YeS, yiyi vplyv na sklad i zmist zvitiv yevropeyskykh kom-paniy ta perspektyvy dlya Ukrayiny [EU accounting directive and its impact on the structure and content of the reports of European companies and the prospects for Ukraine], Bukhhalterskyy oblik i audit - Accounting and audit, 7, 3-15 [in Ukrainian].

Bibliographic description for quotiong:

Dorosh N. I., Horobets I. V. (2019). Organization and Standardization of Sustainability Reporting. Scientific Bulletin of National Academy of Statistics, Accounting and AuditNaukovyy visnyk Natsionalnoi academiyi stattystyky, obliku ta audytu, 1-2, 40-51 [in English]. 